\title{
Bringing the battle to Britain: Band of Brothers and television runaway production in the UK
}

Article

Accepted Version

Knox, S. (2020) Bringing the battle to Britain: Band of Brothers and television runaway production in the UK. Journal of British Cinema and Television, 17 (3). pp. 313-333. ISSN 1755-1714 doi: https://doi.org/10.3366/jbctv.2020.0531 Available at https://centaur.reading.ac.uk/77377/

It is advisable to refer to the publisher's version if you intend to cite from the work. See Guidance on citing.

To link to this article DOI: http://dx.doi.org/10.3366/jbctv.2020.0531

Publisher: Edinburgh University Press

All outputs in CentAUR are protected by Intellectual Property Rights law, including copyright law. Copyright and IPR is retained by the creators or other copyright holders. Terms and conditions for use of this material are defined in the End User Agreement.

www.reading.ac.uk/centaur

\section{CentAUR}


Central Archive at the University of Reading

Reading's research outputs online 


\title{
Bringing the Battle to Britain: \\ Band of Brothers and Television Runaway Production in the UK
}

\author{
Simone Knox
}

\begin{abstract}
:
This article explores the development and pre-production history of the $2001 \mathrm{HBO}$ miniseries Band of Brothers. It does so via a combination of original archive research (conducted at the BFI Reuben Library) and interviews with several industry figures with relevant professional experience, including the current Head of Recorded Media for UK trade union Equity (John Barclay) and the former director of regional film commission Herts Film Link (Roger Harrop). Using these methodologies, the article identifies Band of Brothers as the first significant US runaway television production in the UK, and uncovers how this HBO programme came to benefit from British film tax relief. Here, close attention is paid to dubious practices concerning tax policy and contractual agreements for actors, especially Damian Lewis’ pay. The article demonstrates the impact Band of Brothers has had on television production in the UK in terms of providing Equity with a useful precedent when negotiating for subsequent international productions such as Game of Thrones (2011-2019). Band of Brothers offers important and timely lessons to be learned, especially given the recent growth of US television runaway productions in the UK.
\end{abstract}

Keywords: co-production; British film; tax policy; Equity; the Cultural Test; Steven Spielberg; New Labour; Damian Lewis; creative labour; production studies. 


\section{Introduction}

Even a cursory glance at the credits of contemporary US films and television programmes confirms the success of a considerable number of British and Irish actors in high-profile productions. They have been regularly cast in leading roles, often playing figures deeply resonant with the US public imagination - indeed, the only president featuring on Mount Rushmore National Memorial not to have been portrayed (thus far) in recent years by a British or Irish actor is Theodore Roosevelt. ${ }^{1}$ A complex transatlantic industrial framework has facilitated this movement of labour (Knox 2018), but one crucial factor has been a shift in the US industry mindset following the success of the $2001 \mathrm{HBO}$ miniseries Band of Brothers. While this programme featured nineteen American actors in the major parts, a large proportion of the high number of speaking roles were taken by British and Irish performers including Jamie Bamber, Michael Fassbender, Dexter Fletcher, Tom Hardy, James McAvoy, Andrew Scott and Marc Warren; while Damian Lewis played the lead role. Their well-regarded performances helped to challenge long-standing binary views that regard British actors as more suitable for the stage and Americans for screen-based work (Knox and Cassidy 2019).

This article argues that Band of Brothers' importance extends beyond helping to shift US industry attitudes about British and Irish actors. It also represents a significant turning point in the broader relationship between US and British television production, especially in terms of how key policies and stakeholders sought to attract inward investment, in ways that raise important questions about national identity (especially Britishness). Following John Hill's argument that issues concerning the 'national' inform a range of industry and reception discourses and remain 'an important political and legal matter' (2016: 707), this article explores issues of 
national identity by paying attention to Band of Brothers' development and preproduction periods. While it does not go into detail about broader political dimensions or the full complications of the history of the tax regime, the consideration of tax deals, contracts and pay provides an illuminating insight into contemporary transatlantic television production, particularly in relation to casting, location and financing.

The article combines original archive research conducted at the BFI Reuben Library with insights gleaned from in-depth interviews. The most significant interviewees were John Barclay (Head of Recorded Media for Equity, the UK trade union for professional performers and creative practitioners) and Roger Harrop (the former director of Herts Film Link, accredited in 1997 as a regional film commission focused on attracting productions to Hertfordshire). These key sources are supplemented with information gathered during interviews with an experienced London talent agent (who asked to be kept anonymous) and actor Phil McKee (who played Maj. Robert L. Strayer). ${ }^{2}$ While interviews are necessarily marked by subjectivity, selectivity and memory, all four are 'exclusive informants' (Bruun 2016) whose professional involvement in Band of Brothers provides unique knowledge. By drawing on their interlocking perspectives, I aim to give "new insights into otherwise opaque industrial processes.' (Banks et al. 2016: xi)

Despite its high profile - the series was executive produced by Steven Spielberg and Tom Hanks following the success of Saving Private Ryan (1998), and won a Golden Globe and several Emmy awards - Band of Brothers has attracted rather scant scholarly attention. It deserves greater consideration, not least because despite some press criticism that it presented viewers with moral certainties concerning America's 'Good War' - it problematises notions of national identity. The 
programme does this to some extent textually: the first few episodes contain striking moments where national identity is presented as performative, or shown to be uneasily entangled with historically contingent issues of citizenship and ethnicity. For example, in episode two, a captured German soldier turns out to be a Volksdeutscher from Eugene, Oregon. However, such moments disappear once the narrative gathers momentum. Band of Brothers raises issues of national identity most forcefully through its extra-textual status.

Co-production or runaway? Band of Brothers' transatlantic status It might not seem surprising that Band of Brothers was shot in the UK with British and Irish actors, given that it is commonly known as an $\mathrm{HBO}-\mathrm{BBC}$ co-production. One could expect to find such performers in a transatlantic co-production, especially one made in the UK. However, US-UK co-productions have traditionally seen an insistence by the US partners that Americans feature in leading roles. Caroline Torrance, former Head of International Drama at Granada International, has stated that:

Showtime, HBO and Turner are absolutely one hundred per cent co-producers and they'll be very demanding editorially. You have to put American actors in, usually at least two well-known American actors... The first actor you see has got to be an American actor. (My Beautiful Son [aka Strange Relations, 2001, co-produced by Granada Television and Showtime Networks,] can't open in Liverpool with Julie Walters, even though she's quite well- known. (in Steemers 2004: 117)

All BFI archive materials, as well as press and industry reports of the time, suggest that the BBC was not involved in the initial stages of Band of Brothers and had very little to no editorial involvement. One newspaper noted that the BBC 'had no 
say in the script or casting' (Born 2001: 9), a view supported by Roger Harrop's recollection. $\mathrm{HBO}$ was keen to bring in the $\mathrm{BBC}$ because it felt the Corporation's prestige (Elliott 2013) would help with licensing the programme across the globe. The $\mathrm{BBC}$ invested a comparatively small sum of money in Band of Brothers, paying approximately $£ 5$ million for the UK broadcast rights of a project that had a budget of roughly $\$ 120$ million. It is telling that in interviews at the time, $\mathrm{BBC}$ personnel repeatedly referred to the programme as an 'acquisition', not a co-production (e.g. Tutt 2001). This may also help to explain why the original plans to schedule Band of Brothers on $\mathrm{BBC} 1$ were abandoned, with the show moved to minority channel $\mathrm{BBC} 2$, where it was first broadcast almost a month after the pre-9/11 premiere on HBO.

'Co-production' has tended to be used as an umbrella term to cover projects with varying levels of creative input by the involved parties (see Hilmes 2014), but I agree with Nelson (2019) that it is worth being a little more cautious with such terminology. ${ }^{3}$ Based on the available archive materials (especially the BFI's Band of Brothers information folder) and interview testimony by Harrop and Equity's John Barclay, Band of Brothers is, I suggest, more meaningfully understood as a US runaway production made in the UK (that was, or eventually became, defined as British) than a co-production. ${ }^{4}$ In contrast, even though the BBC also put in a limited amount of money into Rome (2005-2007), this high-budget project, shot at Cinecittà, is better understood as a co-production between BBC, $\mathrm{HBO}$ and (to some extent) Rai Italia (see Nelson 2019); with the BBC meaningfully involved in the initiation and development of the project. 
Running away to Hatfield (again): British efforts to secure production in the UK That Band of Brothers was shot in Hatfield, Hertfordshire, might seem unsurprising, given that parts of Saving Private Ryan (1998) had been shot at the former aerodrome, with its hangars and 1,100 acres, close proximity to London, Heathrow airport and the 'advantageous infrastructure' (McDonald 2008: 228), services and production crew available 'in the NW London wedge' (Harrop). As Champion points out: 'Commonly, firms and individuals who have worked together previously will reassemble for further project work aided by their past experiences and expectations.' (2016) With the production of Saving Private Ryan 'running like clockwork', Harrop recalls discussions of a follow-up project between Spielberg, Hanks and Herts Film Link already emerging during the shoot, with the initial intention 'to save all the sets and some of the props so that the next production could pick up on it'. 5

Nevertheless, that Band of Brothers would be made in the UK was a far from foregone conclusion. Although Hanks and Spielberg had reportedly considered shooting in North America, a runaway production was far more likely, given the costs involved in a project of this size and the presence of a global production infrastructure that, as Michael Curtin has pointed out, allows producers to 'shop around for shooting locations.' (2016: 677) This is precisely what happened. With Vancouver and Toronto 'the busiest locations for North American Screen production after Los Angeles and New York,' (Champion 2016) Canada has been traditionally the most successful runaway production site internationally and so was competing for Band of Brothers. Another possibility was the Czech Republic, a comparative newcomer on the international media production landscape, which, as Petr Szczepanik has detailed, entered a boom period in 1998 that transformed Prague into 'a regional hub of international media production, attracting Hollywood on the prospect of a large, skilled, 
nonunion labor pool and, later on, a 20 percent rebate program.' (2016: 88) Finally, as Harrop recalls, the producers of Band of Brothers were also considering Ireland as a production base. Having previously offered tax concessions and support by its army to secure parts of the production of Saving Private Ryan and Braveheart (1995), the Republic of Ireland's bid was especially strong.

With such fierce competition and with a remit of attracting inward investment, Herts Film Link was acutely aware of what a production of this scale would mean to the local and national screen industry and associated economy. Band of Brothers was set to bring in tens of millions of pounds in contracts covering specialist equipment, building materials, transport and consumables, and provide significant employment opportunities for above- and below-the-line talent. As Harrop notes, this production was 'three times bigger than Saving Private Ryan'; and Herts Film Link's Chris Holt and Karen Miles visited executive producer Tony To and co-producer Ivan Schwarz in Los Angeles - 'to sell the idea of Hatfield again.' They brought with them a specially-produced marketing pack, referring back to the positive experience of shooting Saving Private Ryan and outlining the comprehensive package of local services they would be able to provide. The latter would include dealing with environmental agencies, road closures and the particular needs of the project (such as night-time gun fire near residential areas) - anything, Harrop notes, that 'helps smooth the passage'.

In parallel to Herts Film Link's efforts, the British Film Commission, the Department for Culture, Media \& Sport, the Ministry of Defence and, reportedly, Prime Minister Tony Blair, also endeavoured to help secure production in the UK (aware that the sterling appreciation of the late 1990s would be a factor in the decision-making process). As Curtin notes, 'national leaders are alert to the putative 
value of media as an instrument of "soft power," potentially enabling them to exercise political and cultural leadership on a wide range of issues'. (2016: 674) This was a priority area for the New Labour administration. As Hill has pointed out, 'in 1998, the Department of Trade and Industry published a White Paper with a foreword by Tony Blair identifying "knowledge, skills and creativity" as the country's "most valuable assets"' (2012: 342). With media productivity commonly seen as a telling indicator of a nation's productive capacity and cultural influence (Curtin 2016), Blair's

Government was keen to promote itself as "the vanguard of a new, "creative", "cool" Britain' (Miller et al. 2005: 163).

In this particular context, New Labour evidently did not only want to not lose the follow-up to Saving Private Ryan - which had happened under John Major's 'uncool' Tory government - but do better by not losing parts of the production to Ireland. Band of Brothers was repeatedly identified as 'a vital production' for Britain by Culture Secretary Chris Smith (Smith 2001), and the support it received was commensurate with this assessment. The Ministry of Defence promised extensive support to the project, especially in terms of training. Developers were asked to suspend their plans to re-develop Hatfield until production was complete, which further involved Herts Film Link liaising with the local district council and resident groups. Moreover, Hatfield itself was also made available to the production, as Schwarz put it, 'for an incredibly good fee - for a song, compared to Private Ryan... There had to be a grand sweeping gesture, and that was it. That was the big incentive to come here.' (in Nathanson 2000: 40) In newspaper and trade press reports of the time, a number of different concessions - sometimes the support by the Ministry of Defence, at other times the very competitive price for Hatfield - were identified, by Schwarz and others, as the deciding factor in the decision to shoot in the UK. This 
hints at the strong negotiations that were taking place at the time; however, the actual single biggest concession demanded by the production, which concerned British tax policy, received considerably less coverage and deserves careful scrutiny.

Tax doesn't have to be taxing: Band of Brothers and British film tax policy Important research has charted the long history of tax policy for film production in the UK, such as the Dalton Duty and the Eady Levy. Hill has noted the 'Janus-faced character of British film policy - of looking both inwards and outwards for financial investment' (2016: 709), whereby even supposedly protectionist measures to help 'indigenous' film production would allow international (i.e. US) involvement and investment, often in the form of projects that were 'technically defined as British' (Gornostaeva and Brunet 2009: 23). Hill argues that this is not coincidental or accidental, but needs to be understood as an ab initio policy strategy: ...from the 1920s onwards, there has been a degree of acceptance of the British film industry's dependence upon Hollywood involvement and thus a degree of ambiguity in the way in which a 'British' film has been defined (and how 'national' film policies have been pursued). (ibid.: 719)

This long-standing tension between supporting 'indigenous' productions and attracting foreign inward investment, which in turn renders filmmaking in the UK largely a service film industry dependent on US financing and runaway productions, was further accentuated by a number of initiatives slightly preceding Band of Brothers' development. After lobbying for government action to address the production crisis of the late 1980s, a new tax incentive was introduced under Section 42 of the 1992 Finance (No. 2) Act. This 'allowed British films with a budget in excess of $£ 15$ million to deduct expenditures, upon completion of the film, over three 
years. This incentive served to bolster Hollywood investment in the British film industry.' (Gornostaeva and Brunet 2009: 24) With New Labour's already noted keenness that the UK become a global creative hub, the new Blair government introduced a further tax relief, under Section 48 of the 1997 Finance Act, which allowed a $100 \%$ write-off of costs upon completion. These were very generous incentives that offered substantial savings for a production the size of Band of Brothers.

The legislative acts above refer to 'British film' production, which raises the question of how these can possibly have a bearing on Band of Brothers, an American television programme. The answer to this is two-fold, and I will turn my attention first to the 'British' in 'British film' production. Hill notes that the Film Policy Review Group established by New Labour in 1997 had recommended the introduction of cultural criteria in definitions of what a British film is, but this was not pursued, and the '1999 [Films Act] amendments... did not fundamentally alter the emphasis upon what might be regarded as economic factors.' (2016: 710) However, what the government - part of a long-standing British 'willingness to maintain relatively elastic definitions of a 'national' film' (ibid.) - did fundamentally alter was Band of Brothers' eligibility for the generous British tax reliefs available via these economic criteria.

Band of Brothers would be eligible for British tax incentives if it qualified as British, which meant that $70 \%$ of its production budget had to be spent in the UK and $70 \%$ of the labour had to be sourced from Britain (or the European Community). ${ }^{6}$ The stumbling block here was that UK costs associated with foreign personnel were classified as foreign spend. With Band of Brothers having nineteen American actors in the main roles and thus necessarily present for much of the UK production period, 
these 'foreign costs' were far from insignificant. Film Minister Janet Anderson commented at the time that: 'If a foreign star or producer who is working on a film stays at a London hotel or rents an expensive house in, say, Hampstead, that should count in the film's favour, not against it, because the money is being spent in the UK' (in Anon. 2000: 3-4). Keen to correct this - to borrow a term from the British Film Commission - 'anomaly' (Anon. 2000: 4), the British government thus changed the law on 1 February 2000, amending the British Film Definition through changes to the calculation of labour costs. This helped to ensure that Band of Brothers could legally qualify as British and thus take advantage of British film tax incentives. Fulfilling the stipulated criteria, Band of Brothers was able to write off its production costs under Sections 42 and 48 (also known as a sale and lease-back deal), thereby offsetting a percentage of its budget. Estimates of the percentage figure here vary, with some reports referring to $7-8 \%$ (Gritten 2000) and others to $10 \%$ (Tutt 2001); certainly, the change of the law facilitated substantial financial support. While the Department for Culture, Media and Sport insisted that this legislative change was not intended purely to support Band of Brothers, Screen Finance reported that 'HBO made it clear from the early planning of the series that the amendment was needed if production was to go ahead in England.' (Anon. 2000: 3)

So, this explains the 'British' in the question of how Band of Brothers benefitted from a tax policy for 'British film' production: it was (or became) 'British enough'. As far as the 'film' part is concerned, here the minutes of the debates between Paymaster General Dawn Primarolo and a number of MPs on New Clause 21 in the House of Commons on 3 July 2002 prove illuminating. Following representations by the British film industry, there were concerns that the film relief had been used in ways not in keeping with its original intention, which was to provide 
support for the British film industry, required because of the latter's 'long-standing structural problems' (Primarolo in House of Commons 2002: 260). Primarolo opened the discussion by noting that the television industry, including the production of 'high-value TV drama - drama costing more than $£ 1$ million an hour to make’ (ibid.: 250-251), works on a different structural model with less inherent risk. This provoked several responses, including one by Chris Smith, who as Culture Secretary had been closely involved in helping to secure Band of Brothers' UK production. Following the reshuffling of the Blair ministry in 2001, Smith here argued as a backbencher MP that 'high value mini-television series, especially those made with inward investment money in the UK' (in House of Commons 2002: 255) were in line with the relief's stated aims of promoting growth and opportunities in the British film industry, as 'they are films in all but name.' (ibid.) Reserving criticism for soaps, game shows and 'run-of-the-mill television series', he commented that 'the making of these [highvalue] mini-series has helped to sustain the infrastructure of the film industry, especially in the past year and a half when times have been difficult for parts of the industry.' (ibid.: 256)

Amongst several implicit allusions, Smith explicitly named Band of Brothers as a significant point of reference:

With those high-value television series, there are major employment and skill benefits for us here in the UK. In the past year, for example, $£ 173$ millionworth of inward investment came into the UK to assist the making of such major television series. A large segment of that was the HBO series "Band of Brothers" .... The employment consequences of that inward investment were substantial, as were the opportunities that were given to people in the UK to... develop their skills, and to find employment not just directly on the movie 
sets, but in all the ancillary occupations around the making of television programmes and movies. I fear that as a result of the decisions that the Government have taken, we will lose such opportunities in the future. (ibid.: 255)

Smith's last comment here brings us to the nub of his concern, which is part of a long-standing fear in both British politics and the British film industry of losing out on inward investment to global competition. Rebuffing the view that facilitating tax relief for television production would be setting a worrying precedent for other highrisk industries, Smith repeatedly pointed to the dangers of global competition. He insisted that the television 'industry is... ready to move a major investment in production from one tax environment to another, depending on the relative attractions of those tax environments; much more so than virtually any other industrial activity.' (ibid.: 258) This argument would be vividly exemplified only two years later by the abrupt end of the Czech runaway production boom in 2004, when Hungary introduced new tax incentives and 'foreign film investment fell 70 percent in Prague' (Szczepanik 2016: 93).

The views expressed by Smith and others notwithstanding, Primarolo confirmed the decision to return the relief to the use for which it was originally intended, with New Clause 21 restricting several sections of the Act (including 42 and 48) for films genuinely intended for theatrical release. She reflected that:

The cost to the Exchequer of the use that was made of the relief... rose hugely last year and this year. In 2001, the cost was $£ 180$ million, and it is estimated to rise to $£ 290$ million in this financial year... the Government had to make a judgment on whether... that was a good use of taxpayers' money. (Primarolo in House of Commons 2002: 251) 
Evidently, the use of the relief for television projects like Band of Brothers had come to be viewed critically by the time of New Labour's second term in office. Primarolo considered the use of the relief for television in terms of 'misuse' and even 'abuse', and highlighted that the 'relief was never intended to help to subsidise American companies' inward investment in making dramas for television' (ibid.: 261), referring to Band of Brothers in all but name.

However, it is worth pointing out that the repeatedly-stated commitment to support the British film industry and to behave 'fairly in relation to taxpayers' legitimate expectations' (ibid.: 262) seems to have been much easier to adhere to when it comes to American television than to American film productions. ${ }^{7}$ The hypocrisy here becomes accentuated by both the history of the lengths to which successive British governments have gone to secure US productions (see Stubbs 2009), and what transpired only a few years later during New Labour's third term in office. In 2007, when the introduction of a 'Cultural Test' to connect definitions of British film to more explicitly cultural criteria was required by European Union legislation, the rules of the test were set in such a way that (even with subsequent revisions required by the European Commission) films like Captain America: The First Avenger (2011) would qualify as British, and thus receive British taxpayers' money..$^{8}$

Game of pay: Equity and actors' contracts

With the employment of a large number of British and Irish professionals enabled and prescribed by shooting in the UK, Band of Brothers proved to be a game-changer in Britain for the wider working contexts and conditions of actors employed on this type 
of television production. Barclay points out the difficult balancing act unions such as Equity have to manage in the context of global screen production:

It's a tough task that we all face. How do we react to an American producer coming to the United Kingdom to do Band of Brothers or Game of Thrones? Band of Brothers was really the first that came. And this union had to take some difficult decisions, because you always work under a threat: 'Well, if you don't help us out, we'll go to Hungary. We'll go to Romania.' So you've got to balance the threat and how real that threat is.

This threat of losing out on employment opportunities to competing nations is underscored by the highly precarious working context of actors in the UK, where the majority of Equity members have had to contend with very high levels of unemployment for decades.

Stressing the difference between the contexts of film and television contracts, Barclay explains that Equity had no precedent for the contractual agreement applying to the actors on Band of Brothers. Recalling his own close involvement in the case, he notes that: 'we had to find our way through there, because it's the first time we ever had to do that.' Barclay expands:

there was a deal to be struck on Band of Brothers because our agreement at that time was inward looking; it was a British TV production agreement that really hadn't encountered the nature of this type of [big, international] production ever before. So, we had to then add bits to the contract to accommodate what they wanted. It got a bit messy at the time, but we got there and we're certainly in a better place now than we were when it was made. 
Indeed, Band of Brothers provided Equity with valuable experience that proved useful for further transatlantic television productions, the most notable of which is HBO's flagship drama Game of Thrones (2011-2019). Employing an international crew and a cast dominated by British and Irish actors, the series was shot in a number of countries and locations, including the Titanic Studios in Belfast. Barclay comments:

'Game of Thrones was... encouraged to go to Northern Ireland because the government there gave them lots of tax breaks and places to work in the docks.' Barclay stresses that the precedent provided by Band of Brothers proved especially useful, as Equity needed to accommodate the multi-platform fragmentation of the industry to ensure that Game of Thrones' actors would be appropriately paid.

Phil McKee remembers that the US actors on Band of Brothers 'were pretty shocked and surprised when they heard what we were getting paid.' Indeed, the British and Irish actors received less than their American colleagues, even when taken into account that those with smaller roles would be getting smaller fees. The main reason is that television agreements for actors are constructed very differently on both sides of the Atlantic. However, the contracts for the British and Irish performers were actually more favourable than they may have initially appeared. As Barclay observes:

With the American television agreement, you get high up-front fees with lower percentages for overseas sales and any other activity, whereas our [Equity television agreement] has lower up-front fees but higher repeat structures, higher royalty percentages and is calculated using different methodologies.

The US actors could have been employed under the Equity agreement, but were not, because of the American actors' union's Global Rule One, 'which does not permit members... to work without a SAG contract no matter where production takes place.' 
(Wicker 2003: 485) Barclay explains that it is possible for this to be waived for runaway productions:

So what that means is that, if on Game of Thrones or if on 24 that was filmed here, or on Galavant or any of the other American productions in the United Kingdom, the British engaging company has to request what they call a GR1, a Global Rule One waiver, so they apply to SAG-AFTRA, ${ }^{9}$ SAG-AFTRA contact me and ask: 'Are all the performers being engaged under the terms of an Equity contract?' I go back and say yes, and they allow the waiver. That means [the performers] don't have to be engaged under a SAG-AFTRA contract, they'll be engaged under a British contract, as long as the producer pays pension and health contributions and obligations under the SAG deal... Equity attempted to get the US actors employed under their own agreement, but - and this is where it 'got a bit messy' - Global Rule One was enforced. An article in Stage at the time noted that the agents of the US performers had already agreed to the deal, keen to secure such a high-profile opportunity (Dowell 2000). Therefore, the Americans got more money up-front, but missed out on the ongoing back-end payments provided to their British and Irish colleagues, whom Barclay views as 'probably the best paid performers, ever, that we've had in terms of royalties, residuals and repeats.' This may sound like a strong claim, but it is backed up by the programme's commercial success beyond its initial broadcast. Debra Ramsay notes that Band of Brothers is 'not only HBO's best-selling DVD, but also the highest grossing TV-to-DVD release to date' (2013: 1) and has also 'done well in syndication, with [its] connection to dates of commemoration guaranteeing annual repeats.' (ibid.: 8)

So, even though Equity 'ensured that the [British and Irish] performers 
engaged on it receive fair remuneration' (Barclay) - McKee confirms that he has received payments over the years - there were clearly limits to the union's ability to negotiate for Band of Brothers, especially as the deal for the US performers had already been struck before Equity became involved. More worryingly, these limitations were also evident for one of Equity's own members employed on the production: Damian Lewis. The London talent agent I spoke to remembers that 'part of the deal [for Band of Brothers] was that one of the principals had to be a British actor doing an American accent - that was how they got their funding, they got the deal with the union.' So, Equity was able to facilitate Lewis' casting as Winters; however, the union was unable to prevent contractual manoeuvrings concerning his pay. Despite the fact that he played the lead role of the ensemble cast, Lewis did not get paid more than the nineteen core US actors, because of a contractual clause that stipulated that the Americans would enjoy so-called 'favoured nation status'. This meant that Lewis received a salary that did not proportionally reflect the centrality of his role. ${ }^{10}$

Moreover, Equity was forced to accept that Lewis would be employed on, as Barclay recalls, 'a SAG contract or a lawyer's contract' in line with the SAG minimum agreement, not the Equity minimum agreement, to ensure that he would not receive the back-end payments provided by the Equity agreement; a cost-reduction strategy that Barclay calls 'a classic case of capital and labour.' So, the potential risk of casting Lewis, a British actor then unknown to US audiences, in the lead role, looks more palatable in light of the specific figures involved: for a production with an overall budget of roughly $\$ 120$ million dollars, what Lewis received 'amounted to $\$ 7,500$ per week, but with no extra royalties or residual payments or any extra cash accruing from video sales.' (Dowell 2000: 3) An anonymous Equity source at the 
time expressed the view that a, at the time unnamed, 'UK actor has been stuffed' (in ibid.).

The contractual arrangement and pay for Lewis perhaps might not seem so objectionable as the Band of Brothers cast got to showcase their talent in a highprofile production. Many of the cast went on to develop international careers, and Lewis and his agent Pippa Markham must have thought that this role with its less favourable terms and conditions was a good career move. Certainly, the subsequent return on this investment - Lewis went on to become an A-list actor reportedly commanding \$250,000 an episode for Homeland (Collins 2016) - vindicates this decision. However, considering the sporadic employment, precarious working conditions and generally low pay with which the majority of professional actors have to contend, what if Lewis' career had faltered post-Band of Brothers? What if he was from a less privileged background, and his Band of Brothers income had been his only capital for a very long time? That Equity's negotiations for Band of Brothers were marked by some successes but also some setbacks gives weight to Curtin's point that: As the most ineffable drivers of modern media, talent and creativity are being seriously compromised by the enterprises and institutions that benefit from their labor. Although policymakers in many parts of the world have figured out how to dole out tax breaks and strengthen their institutional infrastructures, the most vexing policy issues invariably revolve around talent. (2016: 681)

Conclusion: Contemporary US runaway television productions in the UK After Band of Brothers' production, the British Film Commission placed full-page ads in the industry press thanking HBO, Spielberg, Hanks and To 'for choosing to 
bring Band of Brothers to the UK' and thanking a number of government and industry stakeholders (including Herts Film Link) 'for making it possible'. The ad's promotional image of a soldier on the ground, holding a rifle aloft, was perhaps intended to convey the idea that a 'heroic struggle' had been involved in the realisation of this project. Hanks repeatedly praised 'the UK's tremendous filmmaking talent and resources' (in Garner 1999: 14), a sentiment echoed by Spielberg when accepting his 2000 Britannia award, which only slightly preceded his 2001 honorary knighthood for his contribution to the British film industry. Such transatlantic backslapping notwithstanding, as this article has demonstrated, in the earlier noted distinction between creative and economic runaway productions, Band of Brothers falls very much within the latter category. Its production history also underlines Susan Ward and Tom O'Regan's point that 'the 'top-down' notion 'runaway' [is] unsatisfying because it tends to obscure the complement of 'bridging' intermediaries and the push and pull factors that are responsible for the relocation of production to specific locations.' (2007: 173; emphasis in original) Band of Brothers certainly was as much pulled as it was pushed to the UK.

Paul McDonald has recognised the film Notting Hill as 'product and metaphor ... representative of the intricate and deep relationships which have characterized interactions between Hollywood and British cinema.' (2008: 224) He does so on the basis that, with British talent, production facilities and locations, a UK-based production company owned by the film's distributor Universal, and dependence on US box office success (which necessitated casting a Hollywood star), 'the film created a little fantasy world that was both London and not London.'(ibid.) Perhaps a not dissimilar argument can be made about Band of Brothers. British effort was instrumental to both the war on which the programme's narrative is centred and the 
realisation of the production itself. However, as the British press was quick to point out (e.g. Smith 2001), the wartime contributions of the British and other allies were narratively marginalised, using British taxpayers' plus licence fee money to do so. The production undoubtedly brought investment, employment and valuable experiences to the British creative (and other) industries, but these were facilitated by some dubious practices as far as tax relief and talent contracts are concerned (about which there has been a good deal of silence). Marked by a questionable mix of British wooing and US strong-arming, Band of Brothers is also highly 'symptomatic of Hollywood's relationship with Britain.' (McDonald 2008: 223)

British television has had a long and complex relationship with North America, with US co-production, co-financing and exporting having been crucial for the production of high-end UK television drama for a long time (Steemers 2004). However, I identify Band of Brothers' production as another significant '[point] at which the presence of Hollywood has registered in the contemporary mediascape of Britain' (McDonald 2008: 220). As the first significant US runaway television production in the UK (see Bignell 2010), Band of Brothers offers important lessons to be learned. Such lessons are especially timely following another change to British tax policy. With concerns about a growing number of British runaway productions in Europe leading to a loss of investment and employment within the UK, ${ }^{11}$ the Conservative-Liberal Democrat coalition government in April 2013 made tax relief available for high-end television.

As with so much of British tax policy for screen production, this move had the benefit of attracting inward investment, with the former loophole now being transformed into legislation. With Scotland, Wales and Northern Ireland having their own tax policies, Game of Thrones was an important point of reference for lobbying 
efforts here (Midgley 2014), having been receiving television tax relief already in place in Northern Ireland. Modelled on film tax relief, the UK television tax relief includes a Cultural Test, with points allocated for cultural content, contribution, hubs and practitioners. This is, unsurprisingly, sufficiently 'Hollywood-friendly' (Hill 2016: 719) to ensure that not only 'British' shows like Sherlock (2010- ) and Downton Abbey (2010-2015), both of which are US co-productions, but also runaway productions like Galavant (2015-2016, shot in England) and Will (2017, shot in Wales) have benefitted from being able to claim a rebate of up to $25 \%$ on $80 \%$ of their UK expenditure. Moreover, while Game of Thrones predates the policy change, a 2015 consultancy report commissioned by a BFI-led consortium comments that the relief helped 'to secure the significant investment and employment' (Olsberg SPI with Nordicity 2015: 7) this US production brings to the UK. Part of the large number of projects being commissioned in US television's current phase of 'peak TV', ${ }^{12}$ these runaway productions are indeed significant: the consultancy report suggested that production expenditure in the UK rose from an estimated $£ 50$ million the year before the introduction of the television tax relief, to $£ 394.7$ million in the first fiscal year of operation, with inward production accounting for $57 \%$ of the spend (ibid.: 43 ). In her work on the role of runaway production in securing a screen industries production base in Scotland, Katherine Champion has noted that Outlander (2014-) 'has almost doubled production spend in Scotland, offering the chance for increased stability for screen industries workers.' (2016)

Given their newness and significance, television runaway productions in the UK certainly warrant careful attention. Union officials like Equity's Barclay are working hard to look after the interests of their members; for him, this involves convening a working party on international television production within the 
Federation of International Actors, to consider 'how best the global unions can react to a global industry'. However, such efforts take place within a wider political context in which 'the long-term strategy of successive governments since 1979 has been to break up unions within the media in order to become a Euro-Hollywood by default' (Miller et al. 2005: 161); and Equity itself was forced to cease operating as a preentry closed shop in 1990. Enabling inward investment has not only been a political imperative, but linked to notions of national pride, such as when Chancellor of the Exchequer George Osborne 'associated himself with the production of Star Wars: The Force Awakens [2015], a film that was not only classified as "culturally British" but also awarded one the largest individual pay-outs under the tax-credit scheme (reportedly over £31 million)' (Hill 2016: 718).

Moreover, Equity is also faced with the industrial reality of high unemployment - it recently estimated that 'around $90 \%$ of trained and qualified actors are out of work at any one time' (The Stage Castings 2015) - and has concerns around low pay, as '[a]lmost half of respondents in [their] most recent pay survey earn less than $£ 5,000$ per year from their professional work.' (Equity 2018) These pressures, and the fact that 'most producers or broadcasters would rather reduce their costs and not pay royalties or residuals' (Barclay), did not put Equity into the strongest possible negotiating position when in August 2015 they were, as Barclay noted:

in the very early stages of thinking about a US production-only agreement that would cover all those American companies coming to the UK, so we would have a direct agreement that would cover all those American companies coming to the United Kingdom to make for their home market and internationally. ${ }^{13}$ 
As Jack Newsinger points out: 'While no one would dispute the value to British film and television workers of inward investment... [t]he primary beneficiaries are the Hollywood studios' (2012: 141-142). As Phil Ramsey et al. (2019) have demonstrated, the economic argument for providing public funding to the likes of HBO - 'welfare for the wealthy' (Guback in Mayer and Goldman 2010) - and claims concerning the beneficial 'Game of Thrones effect' do not fully stand up to scrutiny. With increasing deregulation and market fragmentation, the ever-present fear of losing out to increasingly global competition and the suitability of runaway productions for side-stepping trade union action (Ward and O'Regan 2007), the neoliberal 'race to the bottom as conglomerates hopscotch the globe' identified by Michael Curtin and Kevin Sanson (2016: 7) looks set to continue. Indeed, following the 2013 change to British tax policy, Ireland was quick to increase its tax incentive from $28 \%$ to $32 \%$. Moreover, this downward spiral pertains not only to such percentages, but also the working conditions of creative industry personnel. For example, Romania has had 'few, if any, unions or watchdog groups to enforce safe working conditions' (McDonald 2007: 193); and an online international production guide has no qualms about referring to 'injuries to cast members' (KFTV) during the production of Hatfield \& McCoys (2012) in Romania. Given that European Union legislation has placed restrictions on tax relief policies (including the introduction of the Cultural Test) and provided worker protections (McDonald 2007), the prospect of a post-Brexit Britain only calls for more watchful attention to, as well as the need for trade union and political action regarding runaway productions in the UK, and elsewhere.

\section{Acknowledgments}


I thank my interviewees for generously providing their time and thoughts. 


\section{References}

Anon. 'Government changes UK film law' (2000), Screen Finance, 13: 3, pp. 1 \& 3, 4.

Banks, M. et al. (2016), 'Preface', in M. Banks et al. (eds.), Production Studies, The Sequel!: Cultural Studies of Global Media Industries, New York; London: Routledge, pp. ix-Xv.

Bignell, J. (2010), ‘Transatlantic spaces', Media History 16: 1, pp. 53-65.

Born, M. (2001), ‘ $£ 5 \mathrm{~m}$ 'mistake’ revealed as BBC1 relegates Spielberg blockbuster’, The Daily Telegraph, 15 August, p. 9.

Bruun, H. (2016), 'The qualitative interview in media production studies', in C. Paterson et al. (eds.), Advancing Media Production Research: Shifting Sites, Methods, and Politics, Basingstoke: Palgrave, pp. 131-46.

Champion, K. M. (2016), 'A risky business? The role of incentives and runaway production in securing a screen industries production base in Scotland', M/C Journal 19: 3, http://journal.media-culture.org.au/index.php/mcjournal/article/view/1101.

Collins, L. (2016), 'Blue blood, blue collar: Damien Lewis's transformations', The New Yorker, 18 January, pp. 42-9.

Curtin, M. (2016), 'Regulating the global infrastructure of film labor exploitation', 
International Journal of Cultural Policy 22: 5, pp. 673-85.

Curtin, M. and K. Sanson (2016), 'Precarious creativity: Global media, local labor', in Curtin and Sanson (eds.), Precarious Creativity: Global Media, Local Labor, Oakland: University of California Press, pp. 1-18.

Dowell, B. (2003), 'Pay protest over Ryan TV spin-off', The Stage, 4 May, p. 3.

Garner, C. (1999), 'Hatfield prepares for invasion of Spielberg brigade', the Independent, 11 December, p. 14.

Elliott, A. B. R. (2013), 'Rewriting European history: National and transnational Identities in Rome', Historical Journal of Film, Radio and Television 33: 4, pp. 57693.

Equity (2018), 'Professionally made professionally paid', http://www.equity.org.uk/campaigns/professionally-made-professionally-paid/.

Gornostaeva, G. and J. Brunet (2009), 'Internationalization of the production process in the US film industry: The case of the United Kingdom', International Journal of Arts Management 12: 1, pp. 21-30.

Gritten, D. (2000), 'Bringing the battle to Britain', Daily Telegraph, 5 August, p. A7.

Hill, J. (2012), 'This is for the Batmans as well as the Vera Drakes': Economics, 
culture and UK government film production policy in the 2000s', Journal of British Cinema and Television 9: 3, pp. 333-56.

Hill, J. (2016), 'Living with Hollywood: British film policy and the definition of 'nationality', International Journal of Cultural Policy 22: 5, pp. 706-23.

Hilmes, M. (2014), 'Transnational TV: What do we mean by "coproduction” anymore?', Media Industries Journal 1: 2, pp. 1-8.

Holliday, C. (2015), 'The accented American: The new voices of British stardom on US television', Journal of British Cinema and Television 12: 1, pp. 63-82.

House of Commons Hansard Debates (2002), Volume 388, Monday 1st July 2002 to Friday 12th July 2002, London, Columns 249-62.

KFTV (no date given), 'Filming: A practical guide to filming in Romania', http://www.kftv.com/country/romania/guide/production-guide.

Knox, S. (2018), 'Exploring the casting of British and Irish actors in contemporary US film and television', in C. Hogg and T. Cantrell (eds.), Exploring television acting, London: Bloomsbury, pp. 154-70.

Knox, S. and G. Cassidy (2019), 'Game of Thrones: Investigating British acting’, in M. Hills, M. Hilmes and R. Pearson (eds.), Contemporary Transatlantic Television 
Drama: Industries, Programs and Fans, Oxford: Oxford University Press, pp. 181200.

Mayer, V. (2017), Almost Hollywood, Nearly New Orleans: The Lure of the Local Film Economy, Oakland: University of California Press.

Mayer, V. and T. Goldman (2010), 'Hollywood handouts: tax credits in the age of economic crisis', Jump Cut: A Review of Contemporary Media 52, https://www.ejumpcut.org/archive/jc52.2010/mayerTax/.

McDonald, A. (2007), 'Through the looking glass: Runaway productions and “Hollywood economics"', Journal of Labor and Employment Law 9: 4, pp. 879-949.

McDonald, P. (2008), 'Britain: Hollywood, UK' in McDonald and J. Wasko (eds.), The Contemporary Hollywood Film Industry, Oxford: Blackwell, pp. 220-31.

Midgley, N. (2014), 'TV drama tax credit helps put UK in the global game: Rule change helps drive big-budget shoots to Britain', the Guardian, 23 June, p. 31.

Miller, T. et al. (2005), Global Hollywood 2, London: BFI.

Nathanson, P. (2000), 'Steven? It's Tony...', The Times, 4 February, p. 40.

Nelson, R. (2019), 'Boundary collisions in HBO-BBC transnational coproduction: Rome and Parade's End', in M. Hills, M. Hilmes and R. Pearson (eds.), 
Contemporary Transatlantic Television Drama: Industries, Programs and Fans,

Oxford: Oxford University Press, pp. 147-61.

Newsinger, J. (2012), 'British film policy in an age of austerity', Journal of British Cinema and Television 9: 1, pp. 133-44.

Olsberg SPI with Nordicity (2015), Economic Contribution of the UK's Film, HighEnd TV, Video Game, and Animation Programming Sectors: Report presented to the BFI, Pinewood Shepperton plc, Ukie, the British Film Commission and Pact, London.

Ramsay, D. (2013), 'Television's “true stories”: Paratexts and the promotion of HBO's Band of Brothers and The Pacific', InMedia 4, http://inmedia.revues.org/720, pp. 1-15.

Ramsey, P. et al. (2019), 'Screen production on the 'biggest set in the world':

Northern Ireland Screen and the case of Game of Thrones', Media, Culture \& Society 41: 6, pp. 845-62.

Smith, R. (2001), 'We're in this together', the Guardian, 14 May, pp. B16-B17.

Steemers, J. (2004), Selling Television: British Television in the Global Marketplace, London: BFI.

Stubbs, J. (2009), 'The Eady levy: A runaway bribe? Hollywood production and British subsidy in the early 1960s', Journal of British Cinema and Television 6: 1, pp. 
Sweney, M. (2018), 'Netflix hunts long-term UK production base amid race for studios', the Guardian, 14 September, p. 45.

Szczepanik, P. (2016), 'Transnational crews and postsocialist precarity: Globalizing screen media labor in Prague', in M. Curtin and K. Sanson (eds.), Precarious Creativity: Global Media, Local Labor, Oakland: University of California Press, pp. 88-103.

The Stage Castings (2015), 'How actors cope with being out of work', The Stage, 12 February, http://castings.thestage.co.uk/audition-advice/blog/posts/how-actors-copewith-being-out-of-work.

Tutt, L. (2001), 'The art of war', Screen International 1302, 30 March: pp. 15-16.

Ward, S. and T. O'Regan (2007), 'Servicing 'the other Hollywood': The vicissitudes of an international television production location', International Journal of Cultural Studies 10: 2, pp. 167-85.

Wicker, H. S. (2003), 'Making a run for the border: Should the United States stem runaway film and television production through tax and other financial incentives?', The George Washington International Law Review 35: 2, pp. 461-99. 


\section{Notes}

${ }^{1}$ Lincoln was played by Daniel Day-Lewis (Lincoln, 2012), Jefferson by Stephen Dillane (John Adams, 2008), and Washington by Jason O'Mara (Sons of Liberty, 2015). See Holliday (2015) for a discussion of British actors (including Damian Lewis) as 'accented Americans'.

2 Subsequent quotes are taken from my interviews with Barclay (28 August 2015, in person), Harrop (5 February 2018, phone), McKee (15 May 2016, email) and the anonymous London talent agent (2 March 2018, phone).

${ }^{3}$ Nelson argues that the relationship between $\mathrm{HBO}$ and the $\mathrm{BBC}$ that had yielded Band of Brothers and The Gathering Storm (2002) 'had not extended to a coproduction.' (2019: 147)

${ }^{4} \mathrm{~A}$ distinction is made between creative and economic runaway productions as follows: Creative runaways are produced elsewhere 'based on the requirements of the script or the setting or on the preferences of the actors and/or the director. Economic runaways are (projects) outsourced to other countries as a way of reducing production costs.' (Gornostaeva and Brunet 2009: 21) A closely related term is inward investment production, defined as a project 'that is substantially financed and controlled from outside' (ibid.: 29, note 2) the country in which it is produced.

${ }^{5}$ However, Harrop confirms that 'everything was cleared off the site' in the time gap between Saving Private Ryan and Band of Brothers. Despite interest to turn Hatfield into a permanent production base, the site was eventually redeveloped into, amongst others, a campus for the University of Hertfordshire; a very different outcome compared to another former aerodrome: nearby Leavesden. Hatfield's fate confirms the impermanence marking much of screen production (Mayer 2017, Ramsey et al. 2019).

${ }^{6}$ The Mill and Cinesite in London were used for postproduction, making Band of Brothers

'qualitatively different from the classic runaway model.' (Gornostaeva and Brunet 2009: 28)

${ }^{7}$ However, 2004 film tax policy changes tightened regulations for co-productions (Miller et al. 2005).

${ }^{8}$ For a comprehensive discussion of the Cultural Test, see Hill (2016).

${ }^{9}$ In 2012, the Screen Actors Guild (SAG) and the American Federation of Television and Radio Artists (AFTRA) merged to form SAG-AFTRA.

${ }^{10}$ Lewis' comparative under-payment is a far from an isolated case: British and Irish actors cast for US productions tend to get paid much less than their US peers, Hugh Laurie's much publicised extraordinary pay cheque for House, M.D (2004-2012) notwithstanding (Knox 2018).

${ }^{11}$ For example, Robin Hood (2006-2009) and Titanic (2012) were shot in Hungary.

12 It is worth noting here that in July 2019 Netflix announced a long-term lease on Shepperton Studios to establish a production hub in the UK, following frustration with the lack of available studio space,

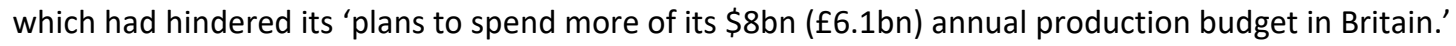
(Sweney 2018: 45) Disney announced a similar deal with Pinewood Studios in September 2019.

${ }^{13}$ In June 2019, Equity signed off on its first direct agreement with Netflix. 